\title{
Defining Moments of the Spirit and Soul in Music
}

\author{
Greg Hurworth
}

\section{Introduction}

This article concentrates on a three-chord sequence, which from each of its occurrences and contexts, seems to be imbued with a similar, special meaning. One might even say at the outset, that this 'meaning' refers to something spiritual and religio-philosophical; specifically, this chord sequence appears to have something to do with the nature of man's deepest relationship to the earth, the universe and to God. In this article, the author intends to discuss the following: the scant times that this chord sequence occurs in music of the past 400 years; the remarkable similarities of use by disparate composers across the centuries, mainly totally unaware of each others' works, and therefore something spontaneous and extraordinary during those centuries; and finally, highlighting the similar meanings of this sequence by comparing the contexts in which it occurs within the music of nine composers, namely: Claudio Monteverdi, Ludwig van Beethoven, Carl Maria von Weber, Anton Bruckner, Gustav Mahler, Richard Strauss, Modest Mussourgski, Piotr I. Tschaikovski, Nikolai Rimsky-Korsakov and Ralph Vaughan Williams. In examples from most of these composers, this three-note sequence occurs in only one work, albeit several times in that work; often the work in which it appears is a quintessential representative of that composer. There may well be further occurrences in the music of other composers in European history, but what is offered here for apparently the first time, is the link between this three-chord sequence and its contextual meaning.

\section{Explaining the 3-chord sequence}

The chord progression referred to in this article is related to a specific melodic outline; therefore, the first step in this article must be to identify the notes of the associated melodic contour. These simple outlines are found as musical example (i). 
Musical example (i):

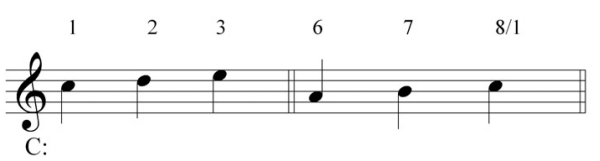

Both these melodic outlines exhibit these characteristics: they exist in a Major tonality; they start on two different notes of the Tonic Major scale, namely notes, and more commonly, note 1 . Each then rises by step through three notes.

Each of the three rising melodic notes is harmonised by a chord; the resulting three chord-sequence, which is the essence of this article, consists of a minor, Major, and finally Tonic Major chord. Several of the examples examined in this article occur in $\mathrm{C}$ major. The resulting chords in sequence for this key are therefore; 'a minor'; ' $\mathrm{G}$ Major' and ' $\mathrm{C}$ Major'. Consequently, the numerical representation of the chords is: vi (indicating the minor chord of the sub-mediant, indicated in lower case throughout this article); $\mathbf{V}$ (the dominant); and I (the Tonic), both of which are Major chords, and written in upper case. Displayed in 4-part homophonic texture, there are at least three possible versions, each with a bass line that moves in opposite motion to the rising melodic line. The first two examples fit with the melodies in musical example (ii) while a third possible and less common harmonisation, with the rising melody in the tenor part, is also displayed.

Musical example (ii):

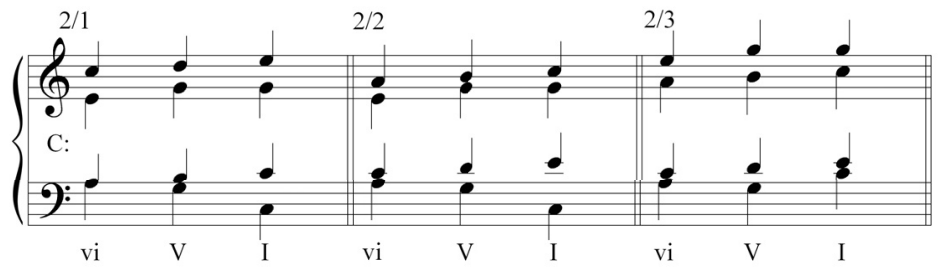

This is not the only way to harmonise this three-note melodic motive. Other harmonisations are to be found within the same works mentioned in this article; but, they can also be found in many works occurring during the Baroque and Classical periods, and are not discussed in this article. Their contextual meanings are different - example $3 / 2$, for example, has three successive Major chords, and often found in music of the $18^{\text {th }}$ and $19^{\text {th }}$ centuries; its context is often associated with so-called 'hunting calls' employing natural horns ${ }^{1}$ or trumpets.

1 Several examples of many from the time period occur in movements one and four of the Jagdsinfonie, the 'Hunting Symphony', also called Sinfonia da Caccia in G Major, for 4 hunting horns, strings and gunshots, by Leopold Mozart (1719-1787), precise date of composition unknown. 
Two common alternatives to harmonising the melodic outline, $1-2-3$, are shown in musical example (iii) as $3 / 1$ and $3 / 2$. The other two harmonisations are also found, but less often.

Musical example (iii):

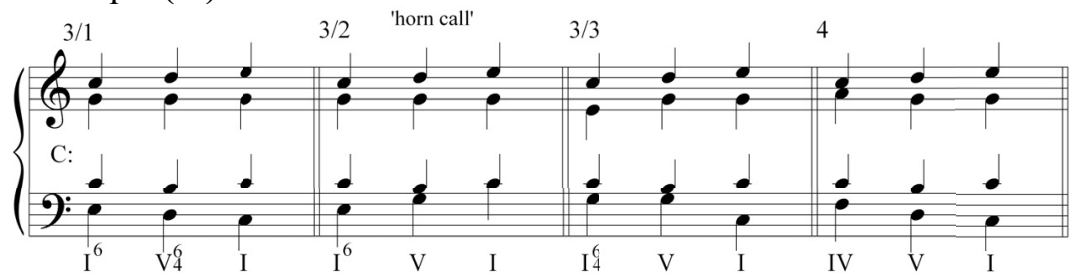

At this stage, it is important to say that there may well be additional uses of the chord sequence, but in this article, a hypothesis is being presented for others to test, refute or affirm based on the facts presented here. This article refers only to the harmonisation with the 3-chord sequence outlined in the first two versions in musical example (ii). ${ }^{2}$

The nine composers in the main canon of European music who use this particular chord sequence can be grouped in various ways, as the discussion below will show. However, here presented in chronological order by composer, are the thirteen examples to be discussed below:

(i) 1610: Claudio Monteverdi: opening of 'Magnificat I', Vespro della Beata Vergine/ Vesperis in Festis Beata Mariae Vergine (The Marian Vespers)

(ii) 1809-1811: Ludwig van Beethoven: Piano Concerto no. 5, 'The Emperor', Op. 73, movement (ii)

(iii) 1820-1821: Carl Maria von Weber: Der Freischütz, Op. 77, Overture

(iv) 1874: Modest Mussourgski: 'The Great Gate of Kiev', from Pictures at an Exhibition

(v) 1882: Piotr I. Tschaikovski: The Year 1812, Festival Overture, Op. 49

(vi) 1881-1883, rev. 1885: Anton Bruckner: Symphony no. 7, movement (ii)

(vii) 1888: Nicolai Rimsky-Korsakov: Russian Easter Festival Overture, Op. 36

(viii) 1892: Gustav Mahler: 'Urlicht', from Des Knaben Wunderhorn, and Symphony no. 2, movement (iv)

(ix) 1896: Richard Strauss: Also Sprach Zarathustra, 'Sunrise', Introduction

(x) 1910: Ralph Vaughan Williams: Symphony no. 1, 'Sea Symphony', movement (iv)

(xi) 1909-1910: Richard Strauss: Der Rosenkavalier, Op. 59, at various times within the opera; and again in 1944, when a Suite taken from the Opera, was arranged for the concert hall.

(xii) 20. 9. 1948: Richard Strauss: 'September', song no 2 from Four Last Songs

(xiii) 6. 5. 1948: Richard Strauss: 'Im Abendrot', song no 4 from Four Last Songs

2 In a couple of instances, discussed below, the third chord of the sequence does not function as the Tonic - but serves as another function within the key, and notably, chord IV. See discussion below. 
Various points can be deduced from this chronological list. Firstly, the most iconic and well-known example of this three-chord sequence, is undoubtedly the cadence at the end of the 'Introduction', a musical depiction of a Sunrise, which begins the 'philosophical' tone poem, Also Sprach Zarathustra by Richard Strauss (1864-1949). The celebrity of this example is in no small part due to its use during the opening credits of the film, 2001: A Space Odyssey. ${ }^{3}$

However, it also needs to be noted that Strauss used this sequence in works that span most of his creative life. His next most notable use of these three chords is in his most renowned opera, Der Rosenkavalier, which premiered in 1911. Notes five, six and seven of the opening tune of the whole work, are those three melodic notes of tonic, supertonic, and mediant, or 1, 2, 3 of the tonic, in this case, E major. He then harmonises them with the three-chord sequence under scrutiny here. In addition to the opening moments of the opera, the chord sequence reappears in the final waltz of Act II. The final cadence closing the orchestral Suite of music extracted from the Opera ${ }^{4}$ forcibly reiterates the three-chord sequence. On this occasion, as in Also Sprach Zarathustra, the cadence occurs in C Major, making a striking musical parallel or self-quotation, between that tone poem and the opera.

The final examples of a life-long use of this three-chord sequence occur in the Four Last Songs of Strauss, completed during 1948. Both Songs 2 and 4, use the sequence twice. Its use in Song 4 is in 'E flat Major' - which alone aligns it with other examples of this sequence, which also occur in the same key. In Song 4, its use occurs five bars from the end of the song, thus forming the final cadence. While this Song was not the last music that Strauss wrote, it has been performed as the fourth of these 4 last songs since 1950, when the songs were first published in that order by Ernst Roth. The final three chord cadence, vi, V, I, in 'E flat Major', comes after the final words of the song - ist dies ... etwa ... der Tod?, meaning 'Is this ... perhaps ... death?' Therefore, this appears to be a fitting final use of this cadence spread across more than 50 years of compositions by Strauss.

A second point is that, from this list of thirteen works, it can be seen that there are three works, composed between 1874 and 1888, a mere 14 years, in Russia by three friends. The point from all of this is that all the occurrences of this chord progression occur in works that quote or closely imitate Russian Orthodox Chants. It appears that the harmonisation of Orthodox chants lends itself to the use of these three chords in

2001 is an iconic film by Stanley Cubrick, which appeared in cinemas across the world in 1968 with great popularity.

4 This orchestral Suite appears to have had the sanction of Strauss, when it was first published in 1945, but it was not made by him. The arranger of this orchestral suite appears to be Artur Rodzinski (1892-1958), who conducted its New York premiere in 1944. We therefore do not know if it was Strauss who ended the Suite in C Major with that cadence, or it was Rodzinski's stroke of brilliance to end it that way. The final cadence of the Suite sounds remarkably like its twin in Also Sprach Zarathustra. In this way, the two works appear to come from the same source and unite the works spread across the years, 1895 to the opera's premiere in 1911, to the appearance of the Suite in 1944 as well as finally with Song no. 4 of the Four Last Songs. 
succession. This regularisation of these chants, and the establishment of Choirs in Russian churches, appears to be an innovation dating from the $18^{\text {th }}$ century. ${ }^{5}$ Rimsky-Korsakov is the link between these composers - indeed, his Russian Easter Overture is dedicated to the memory of his friend, Mussourgski, and he also made the performing edition of the latter's Pictures at an Exhibition, the final movement of which is under discussion below.

Finally, there appears to be no use of this particular 3-chord progression between Monteverdi and Beethoven, covering a period of around 200 years; on the face of it, this is quite remarkable indeed. Of course, this time frame includes a considerably vast body of music, amounting to all the works of the later Baroque, Roccoco and Classical periods, including those of J. S. Bach, Bach's sons, Mozart and Haydn, and on into the early $19^{\text {th }}$ century. As mentioned earlier, the use of the 'hunting call', as outlined by example $3 / 2$, in musical example (iii) above, is an alternative harmonisation of the three-note melody as mentioned earlier in footnote 1 .

In addition to this discussion, it is important to relate the following: the apparent dearth of use of this chord progression during the $17^{\text {th }}$ and $18^{\text {th }}$ centuries can perhaps be explained by this observation. During this time period, use is made of the retrograde version of this three-chord sequence, occurring in reverse order as: Major chord, Major chord, minor chord. (As the music in which it occurs usually uses a 4/4 time signature, there needs to be another minor, or Major chord to complete the bar). This reverse-order version of the three-chord sequence was exceedingly common, and often employed as a recurring pattern (ostinato).

This version occurs at the beginning of a piece and heard as - Tonic [I], Dominant [V], Sub-Mediant [vi]; as an ostinato pattern, it appears to date from the late $17^{\text {th }}$ century. It is easily recognizable in musical example (iv) as the opening and basis of Canon (and Gigue) in D, although how and when it came into existence is still unknown. ${ }^{6}$

The author has no intention in this article to deal with the history of Russian Church Music. For the purposes of the hypothesis of this article, it is necessary to highlight the fact that the three-chord progression here, was most probably established in Russian church music in the $18^{\text {th }}$ century, during which significant reforms of church music took place; the influence and use of Western Renaissance and Baroque polyphony and harmony, established elsewhere in Europe, notably $16^{\text {th }}$ century Italy, certainly appear to have influenced and led these $18^{\text {th }}$ century musical reforms in Russia.

6 One idea is that the piece was possibly written for the wedding in 1694 of Johann Christoph Bach (1671-1721), a brother of Johann Sebastian Bach (1685-1750). It has certainly been popular at European weddings since a modern performance by the Jean-Francoise Paillard Chamber Orchestra was released in 1968 on disc. Furthermore, this recording shot to popularity for its use as background music in the Academy award-winning Robert Redford film, Ordinary People, which appeared in 1980 and thus sealing its prominence in recent popular culture. 
Musical example (iv):

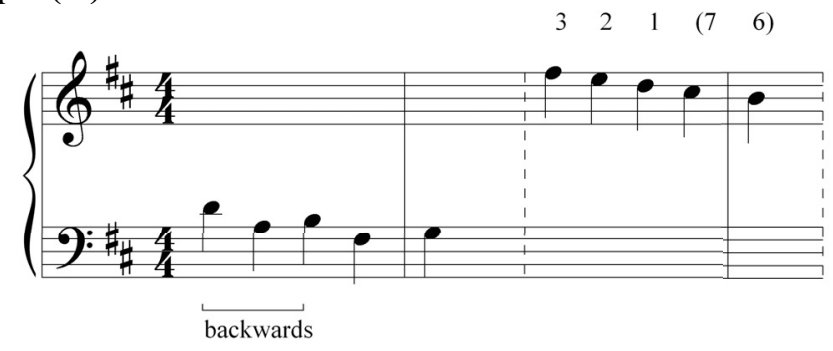

In this Canon by Pachelbel, the retrograde version is used as an ostinato pattern, heard first of all on a single bass or basso continuo instruments, which present the bass part. This pattern became well established, and continues to the present day, by its use in the opening bars of many songs; such songs are from differing styles of Western Popular Music. In fact, it is used as part of a 4-chord progression where the $4^{\text {th }}$ chord is the Subdominant or sometimes mediant chord. Since it is heard at the beginning of a phrase, it is in opposition to the three-chord progression, which is associated mainly with a cadence, at an end of a phrase, section or piece and only sometimes with the opening of a phrase.

Notable modern examples of this ostinato pattern from the past five decades include such popular songs and their singers as: Let it Be (1970, The Beatles); Country Roads (1971, John Denver); No Woman, No Cry (1976, Bob Marley); Take on Me (1985, A Ha); With or Without You (1987, U2); Can You Feel the Love Tonight? (1993, Elton John); You Were Amazing (2001, Alex Lloyd); You're Beautiful (2003, James Blunt); Poker Face (2008, Lady Gaga). This albeit short list of hit songs by some of the most celebrated popular music performers, seems to indicate the following: there appears to be something fundamentally satisfying in the use of these four chords in succession that suits the context and their reception by an audience. This list of performers, the constancy of the use of this 4-chord progression, plus the range of styles and the time frame it covers, all suggest something significant and humanly-satisfying to the listener. Its very familiarity apparently speaks fundamentally to the hearts and souls of so many. ${ }^{7}$

This phenomenon was brought to the attention of the musical world by the Australian comedy Rock Band, Axis of Awesome, who performed a five-minute series of openings to 37 songs using this pattern, during the 2009 Melbourne Comedy Festival. The list presented here is taken from their routine, and examples often use the four chords as an ostinato, in 4/4 time signature, no different at all from the Pachelbel 'original' from over 300 years ago. The surprising use of the sequence is in the Australian folk song, Waltzing Matilda. This folk tune and accompanying harmony dates back to at least the 1890s, and was based on a previous folk tune of nearly 100 years earlier. The use and meaning of the deeply felt, humanly-satisfying instinct provided by this harmonic chord sequence, whose use also spans centuries, is a possible subject for further investigation. The point here is that it is not associated with religio-philosophical content, but more with the idea of story-telling, and love between a man and woman. 


\section{Contexts and Meanings in the use of the chord sequence}

Here follow some brief notes on the use of the three chords as they appear in the musical context of the nine composers. It is the musical characteristics of these contexts that help define their contextual meaning.

\section{Richard Strauss}

It seems best to begin with the Strauss examples. The reason is that his definitive use of this sequence occurs on more than one occasion and in two distinct ways. These two ways are: (i) as final cadential material; and (ii) as help with modulating between phrases. Time to look at each individually:

\section{(i) final cadential material}

The outstanding example is undoubtedly during the opening bars of his orchestral tonepoem Also Sprach Zarathustra; the three chords form a cadence and bring to a close the opening music depicting a sunrise. The music builds from almost inaudible rumblings through to this full orchestral three-chord cadence, including organ at full volume, performed almost overpoweringly loudly. ${ }^{8}$

Perhaps the most significant of the musical facts is that the three chords are performed rather slowly and very distinctly. This lack of speed to their unraveling draws attention to each of the chords, their individual characteristics, as well as their progressive accumulative meaning across the short, yet pronounced sequence. The melodic outline consists of the sub-mediant [note 6], leading note [7], and tonic [8/1] in C Major, which provide the effect of striving upwards towards a satisfying feeling of completion. The music shakes and moves the spirit within us by this three-chord sequence, as Strauss (and the words of Nietzsche) intended us to be.

The other example by Strauss, in 1948, which is some 53 years later than the Zarathustra one, occurs right at the end of the compositional career of Strauss; it is found in Song 4, 'Im Abendrot', (At Night-fall) of Four Last Songs. The major difference between the two examples is that the cadence in this Song is heard softly, and mainly uses stringed accompaniment. The major similarity between the two examples is that the pulse moves very slowly indeed (sehr langsam), as detailed in the score. Again, each chord is highlighted separately in this way, and great symbolic meaning for all three chords in sequence is therefore evident. Once more, the spirit of the listener is engaged - this final cadence of the song follows the words by Joseph Freiherr von Eichendorff (1788-1857):

8 In fact, it is so well-known that there is no real need to show it as an example, here - in addition, it has already been seen earlier in outline in musical example (ii) above. 
Ist dies etwa der Tod? ${ }^{9}$ In these final moments of the song, the three chords are played, very softly, slowly and by the strings. They therefore sound eerily similar to the opening of the Mahler song, discussed below.

The three-chord sequence therefore forms a neatness of conception by being used in the early, a middle work (Der Rosenkavalier), and this final work as a song by Strauss; a further very neat symmetry is formed by examining the example from Zarathustra and the last Song from 1948: the first concerns a sunrise, and the last has a text which refers to sunset, both great examples displayed philosophically of a life journey from beginning to end.

\section{(ii) modulation}

The second way in which Strauss uses this chord progression is as part of a modulation rather than at a cadence. He provides three examples of this in his Four Last Songs - two in Song number 2, 'September', and one in the song, 'Im Abendrot'.

The use of harmony for this modulation is direct and simple. It involves the tonic of a minor key, being treated simultaneously as the sub-mediant of a new Major key. All three examples therefore use the sequence, vi moving to V or V7, to I, or a modulation from a minor key to a Major one, at the distance of a minor $3^{\text {rd }}$.

The first of the two examples is the song, 'September', shows that the point of arrival after a cadence is into the tonic key of 'e flat minor' (musical example (v)). This tonic chord is then treated as the sub-mediant of a new key, in this case, G flat Major, and the modulation is affected by a perfect cadence in that new key. Melodically, the outline is by step - 'g flat', 'a flat' and 'b flat'.

Musical example (v): two examples in 'September'

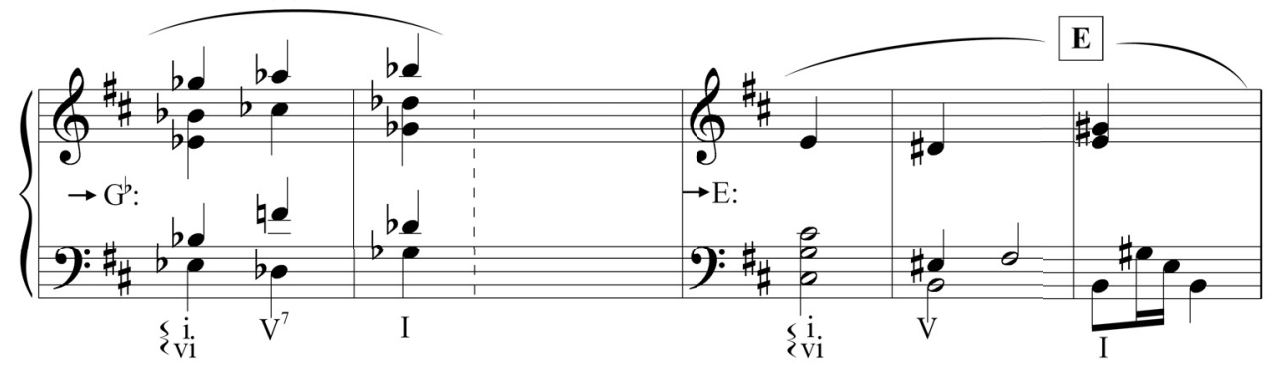

The speed is quite slow, and the second chord is a dominant $7^{\text {th }}$ rather than the basic dominant triad; but the chord progression is not affected. (Besides, the $7^{\text {th }}$ adds a richness to that second chord). In this part of the song, the modulation comes between verses

9 To cement this feeling of finality of life here on earth, Strauss further quotes from his early tone poem of sixty years earlier, Tod und Verklaerung, Op. 24, dating from 1888-1889. 
one and two of the original text by Hermann Hesse (1877-1962). Verse 1 ends with the words in English translation: '[...] Summer shivers in the chill of its dying domain [...]'. The text therefore gives the feeling of something fading away in order to make way for something new. Verse two opens with the words: '[...] Yet summer smiles, enraptured [...]' Summer is the connection between the two verses of text; but, the states of summer expressed are quite different, and Strauss needs to indicate this musically in some way. The way in which he does this is to use a modulation to lift us from one level of meaning and feeling to another, related one.

The second example, as shown in musical example (v), and in the same song, is a melodically ornamented modulation from 'c sharp minor' to 'E major'. The chord of 'c sharp minor' is the tonic, but then actually becomes the new sub-mediant in the key of 'E Major'.

The third example of using the three chords as a modulation occurs in song 4, 'Im Abendrot'. As in the other song, Strauss uses the tonic, in this case the chord of 'a flat minor', to be the sub-mediant of the new key, 'C flat Major', thus procuring the modulation from minor to Major. This is shown in the following musical example, (vii).

Musical example (vii): 'Im Abendrot'

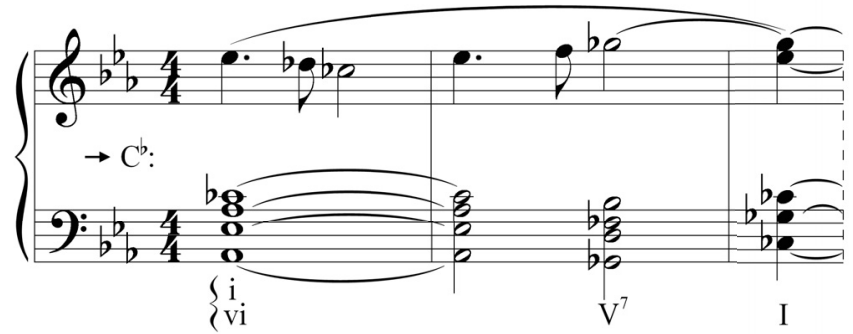

\section{Claudio Monteverdi}

The apparent first use in Western musical history of this three-chord sequence, occurs at the beginning of the 'Magnificat', also known as the Canticle of Mary, in Monteverdi's work of 1610, Vespers for the Blessed Virgin.

We hear the step-wise melodic movement as monody first of all; then follows the harmonised three-chord sequence three times. All this forms the opening seven bars of the 'Magnificat', as seen in musical example (viii). 


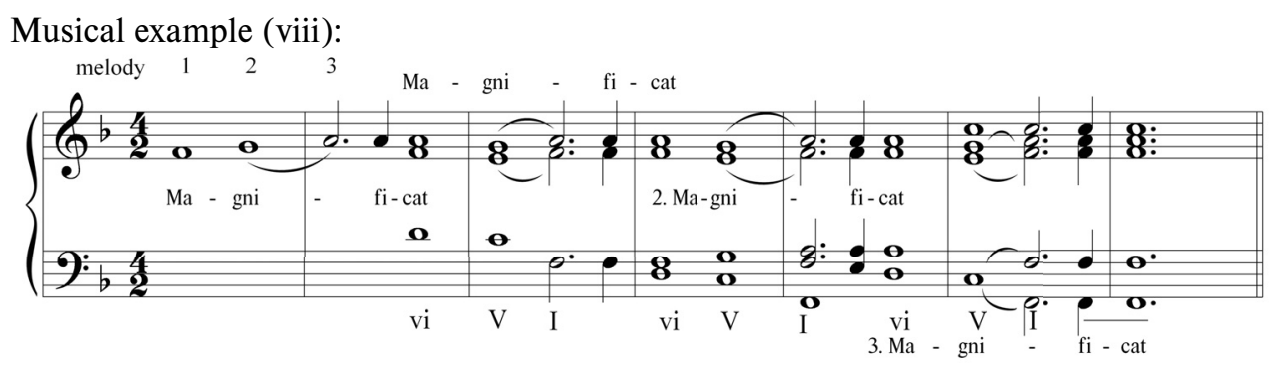

As can be observed, the three statements of the harmonised melody overlap with each other; instead of resolving to the tonic each time, Monteverdi keeps the momentum going by overlapping the third chord with the sub-mediant instead. It is the last of the statements that finally resolves onto the tonic, 'F Major' chord. In this example, the melody, which these three chords support, consists of notes 1, 2, 3 of the tonic scale (indicated over the opening notes in the example). ${ }^{10}$

Significantly, the pace of the notes is slow; we can clearly hear each of the chords in a stark, hymn-like way, highlighting their individual (tonal) qualities separately and in sequence (harmonically). The text employs only one word - magnificat, heard four times, with increasing intensity of texture and resultant rise of dynamic level. This increase in volume is formed by a crescendo of sorts, as more and more sounds are added into the texture. It is the context of this word, magnificat, which links the chords with their contextual meaning; this word is the prelude to the text of the whole of Mary's Canticle, which comes from the Gospel according to St Luke, chapter 1, verse 46 onwards. The text of the first line is: Magnificat anima mea Dominum, et exsultavit spiritus meus in Deo salvatore meo - 'My soul doth magnify the Lord, and my spirit hath rejoiced in God, my Saviour'. ${ }^{11}$

Straightaway, we can see that Monteverdi has identified the three-chord sequence with the words of the text which go on to indicate the 'soul' and 'spirit' of the Virgin Mary, who is saying/singing these words. Not only is Monteverdi's opening an absorbing piece of musical drama, but he is initiating all of Mary's words with music of a three-chord sequence, which appear to be laden with spiritual meanings. In fact, the three hearings of the three chords in sequence can be easily identified as the link between God the Father, God the Holy Spirit who is the Lord, the giver of life, who announces the conception of third part of the Trinity, God's Son, Jesus. In other words, they can be seen to form a symbolic example of the Trinity (Father, Son and Holy Spirit) as sung by Mary (represented initially by the opening three notes sung by the women of the chorus, unaccompanied).

10 In recordings by John Eliot Gardiner, he chooses to use a performing edition with the 'higher' pitch set at a $4^{\text {th }}$ higher - in this case, 'B flat Major' for the Magnificat.

11 This English text was translated for use in the Book of Common Prayer, 1549, and revised in 1552/1604 and 1662. The Latin is commonly used in the Catholic Church, and was translated from the original Greek in the Middle Ages. 
Monteverdi hints at the same chord sequence in the $1^{\text {st }}$ and $2^{\text {nd }}$ Ritornelli sections of the Ave Maris Stella, the preceding movement 12, of the complete Vespers. The words of the verses of this hymn refer to 'Nurturing Mother of God, Star of the Sea, Hail [...] from the mouth of Gabriel, establish peace with us [...]' The words of this hymn addressed to Mary, Mother of God, form a great introduction to the Magnificat, the very words of Mary, which immediately follows. The three-chord sequence thus forms something of a link between the musical setting of the text, Ave Maris Stella, and that of the Magnificat; this further underlines the religious nature of the three-chord sequence in this work.

\section{Ludwig van Beethoven}

Beethoven uses the three-chord progression in a prominently stirring context. This is part of the slow, middle movement of his Piano Concerto, no. 5, 'The Emperor'. This movement is one of Beethoven's highly spiritual Adagio movements, on a par with similar profoundly felt adagios, to be heard in his Sonatas, particularly for Piano, as well as his Symphonies (especially numbers 3, 7 and 9).

In fact, Beethoven uses the progression as part of a three-part sequence, punctuated by two silences, as seen in musical example (ix). The silences are part of the drama; but, at the same time, they allow each of the three statements to stand out clearly, as the pulse moves meditatively slowly (adagio, un poco messo).

Musical example (ix):

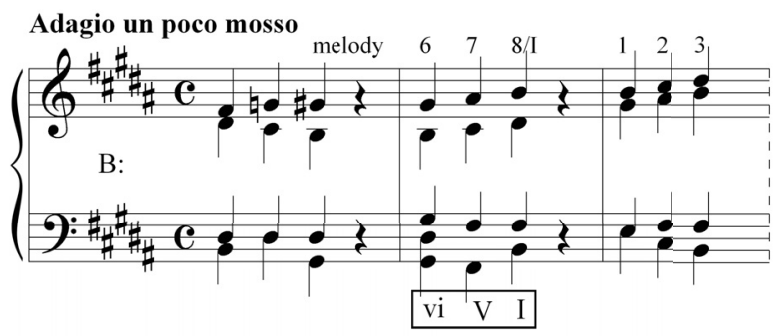

The musical characteristics of this use are as follows: the melody uses consecutive notes in ascending order, as in all the other examples, and is punctuated by a crotchet rest. This rest elongates the third of the three chords, as its sound lingers on in the brain. Each of the three statements is in B Major, but it is only the middle one of the three that uses the three-chord sequence, vi, V, I, and which begins with a minor chord moving through two Major chords. However, it is this middle one of the three statements, which really attracts our attention; melodically, the notes are sub-mediant, leading note, and tonic, comprising in this case, notes ' $\mathrm{g}$ sharp', 'a sharp' and 'b' in the key of B Major. Throughout this example, performed by stringed instruments, not only is the music ascending, but it increases in volume as the melody rises. 


\section{Carl Maria von Weber}

This example by Weber (1786-1826) comes from the Overture to Der Freischütz, Op 77, dating from 1820-1821 and so was written around 10 years later than the Beethoven example. It is entirely possible therefore that Weber had heard and even played or conducted the Beethoven example in concert. Weber was often critical of Beethoven, however, and the relationship of the examples from the two composers, might just be put down to being the use of a common 'harmonic currency' in European music at the beginning of the $19^{\text {th }}$ century. That being said, it might not be so 'common' as an initial reaction might suggest; it is seemingly not used by other contemporary composers of Weber (or Beethoven), such as Schubert, Rossini or Berlioz etc.

That this Opera should become prominent in influencing composers of the next generations, including Richard Wagner (1813-1883), is significant. It is a fact that the opera's story line, along with its music, brings together so much of the emerging national identity of Germany (Deutscheit emergiernd), that makes it important as an example for this article. German identity is shown here through the language and stories being collected in German-speaking areas (including those by the Brothers Grimm, and Brentano); this particular story includes mentions of things close to the German spirit, such as holy men, aspects of the supernatural, the spirit of man, and it is overladen with symbolic spiritual meanings, important for bringing together aspects of Germanic history and culture. All this is moving towards the forthcoming unification of these German-speaking peoples and culture into the single country of Germany (1871).

In the Overture, we hear the three-chord sequence on two different occasions (and musical example ( $\mathrm{x}$ ) shows the first) - this begins in the tonic key of 'c minor'. (The second hearing is virtually an identical copy in the recapitulation section, but this time in the key of 'f minor').

Musical example (x):

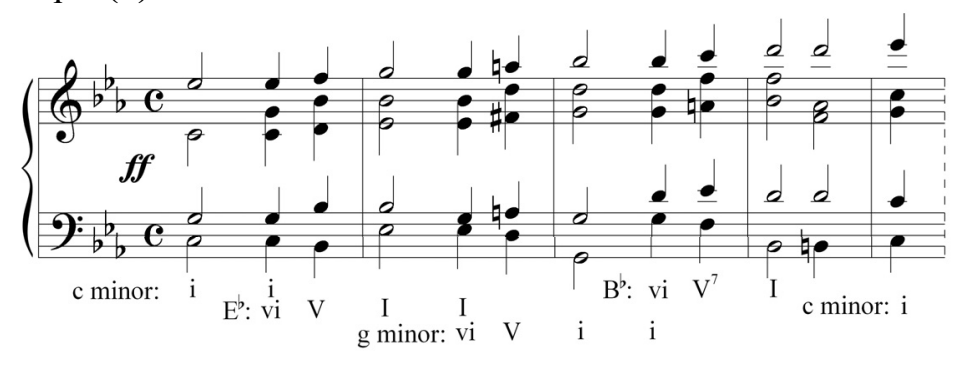

Just as in the Beethoven, we hear the sequence of three chords, three consecutive times. In the Beethoven, however, each time was separated by a crotchet rest; with Weber, the last of the three chords is doubled in length (to be a minim), which gives the same feeling of coming to a pause before the next hearing, as had similarly occurred in the Beethoven. 
The Weber examples can be seen to finish in the keys in which they started, 'c minor' and 'f minor' respectively, in the same way as within the Beethoven example of 'B Major'.

There are two significant differences from the example by Beethoven. The first is that Weber's use is all in the minor mode, while Beethoven's is in the Major. In addition, the pulse moves quite quickly, and the orchestra is full, and playing $f f$. A difference from the other examples is that Weber begins on 'e flat', the mediant in 'c minor', and ends on the mediant note, ' $\mathrm{g}$ ' in the new key of 'E flat Major'. Different from the Beethoven is that it is the first and third hearings of the three-note sequence, which fit the example under scrutiny in this article. As with the later Strauss examples, the three chords initiate a brief modulation, on this occasion, to the relative Major. The middle hearing is heard in ' $\mathrm{g}$ minor' (and 'c minor' in the recapitulation). In other words, Weber has started and finished in the minor key, and the middle hearing is in the Major; Beethoven employs B Major for all three hearings. Both Beethoven and Weber use this three-chord sequence in highly, dramatic ways, which appear to be full of spiritual meanings as shown by their contexts.

\section{Anton Bruckner}

Beethoven's music was certainly among those that influenced the character and meanings found in Bruckner's symphonies. It is not surprising to find that Bruckner's use of the three-chord sequence is confined to a slow movement of a symphony, number 7 . The melody comprising tonic, supertonic, and mediant, is heard three times in the long, slow movement. Importantly, each of the three uses employs a different harmonisation (as shown in musical example (iii) above). The version that best fits this article is heard first, and occurs right at the beginning of the movement, beginning bars four and five of the third phrase; it is shown in musical example (xi). Of note here is that this first chord is actually the tonic, 'c sharp minor', which is then treated as a new sub-mediant in the key of 'E Major'. This therefore fits with the modulatory examples by Strauss, as shown above.

Musical example (xi):

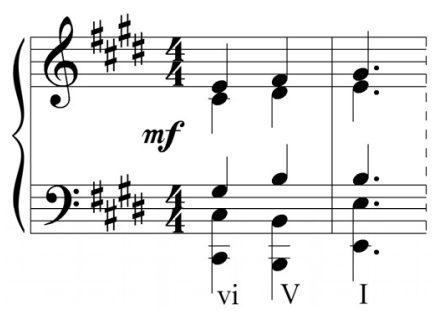

The performance indication is immer fort, (remaining strongly played) beginning $m f$ with a crescendo through the three slow-moving chords, which are played by strings only, using a standard four-part harmony. The second hearing at Figure $G+$ bars 4 and 5, has the same stringed version, but with a sextuplet violin 1 embellishment, as shown in musical 
example (xiii); the first and last notes of each of these violin embellishments of each crotchet is formed of the melody, shown by an asterisk over the initial note of the six.

Musical example (xiii):

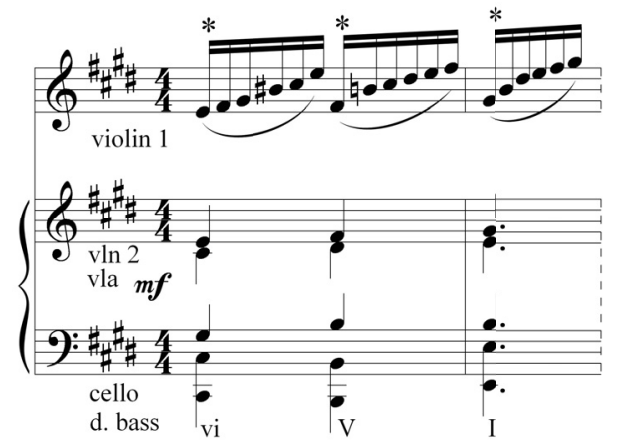

Bruckner's second harmonisation of the ascending three-note melody is to be found at rehearsal figure $\mathrm{D}$, but now in $\mathrm{G}$ Major. (This is a harmonisation as in musical example (iii), $3^{\text {rd }}$ version, [3/3] above). And the third harmonisation is a 'classical', $18^{\text {th }}$ century 'horn-call', heard twice at figures $M$ in 'E flat Major' and V in 'B Major' respectively. The 'E flat' version is displayed in musical example (xiv) and the 'B Major' version in example (xv).

Musical example (xiv):

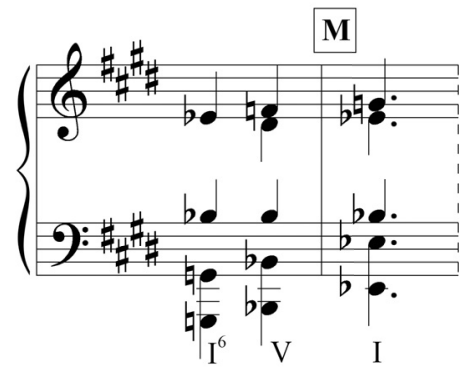

The second of the two 'horn call' examples is remarkably similar to the embellished hearing of the main melody from Mussourgski's 'Great Gate of Kiev', which also has rushing scalic semiquaver passages descending by step. Figure V is shown in musical example $(\mathrm{xv}){ }^{12}$

12 These latter, 'horn call' examples are also heard in other Bruckner works; for example, in movements (i) and (iv) of Symphony no. 4, in which there are brass chorale-like moments within the Development sections of these movements. The pace of the chords in the movements of Symphony no. 4, 
Musical example (xv):

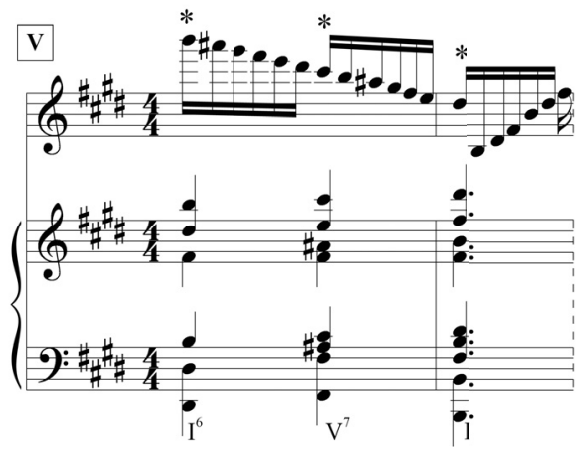

\section{The Russians}

During the $19^{\text {th }}$ century, Russian composers wrote increasingly nationalistic music, which led to a notable and distinct Russian identity through music. Part of this musical identity was the increasing use of chants from the ever-present and powerful Russian Orthodox Church. Such chants used ancient modes, and were collected together and harmonised during the $18^{\text {th }}$ century to standardise musical practice within Orthodox services across the vast country that Russia was becoming.

Modest Mussourgski (1839-1881) appears to be the first of the three Russian composers to include hints of orthodox chanting, with a quasi-quotation from church music; for the context of this article, they occur in his 'Great Gate of Kiev', as part of Pictures at an Exhibition (1874). The complete performing edition of this work for piano was later prepared for publication by Mussourgski's friend, Nicolai Rimsky-Korsakov (1844-1908); the latter then also wrote various works containing quotations from chants, including The Russian Easter Festival Overture, Op. (1888), mentioned below.

Virtually at the same time, Tschaikovksi's Ouverture Solenelle: 1812, Op 49 (1882), opens and closes with the use of one Orthodox chant, as discussed here.

\section{Modest Mussourgski}

'The Great Gate of Kiev' has one main theme, in long held, slow moving notes, which begins with melodic notes tonic, super-tonic and mediant, and which fits the profile of the three-chord sequence in this article; the entire melody, majestically performed $f f$, also rather sounds like an Orthodox chant. (Its harmonisation corresponds to $3 / 1$ from musical example (iii) above; it begins with a first inversion tonic chord).

is also slow and completely majestic, and fits very much with the same spiritual-like quality of the examples from Symphony no. 7 given here. 
However, Mussourgski also uses different harmonisations in the six times we hear that main tune. ${ }^{13}$ It is in the two quieter, contrasting interludes between the main melody where he uses an adapted harmonised Orthodox chant; it is an altered version of a chant used at baptisms. The first time we hear this harmonised chant, it is used in 'a flat minor' as part of a modulation to 'C flat Major' (bb. 30 to 34) as shown in musical example (xvi) below; it is remarkably the same as the modulatory example by Strauss, in musical example (vii) above.

Musical example (xvi):

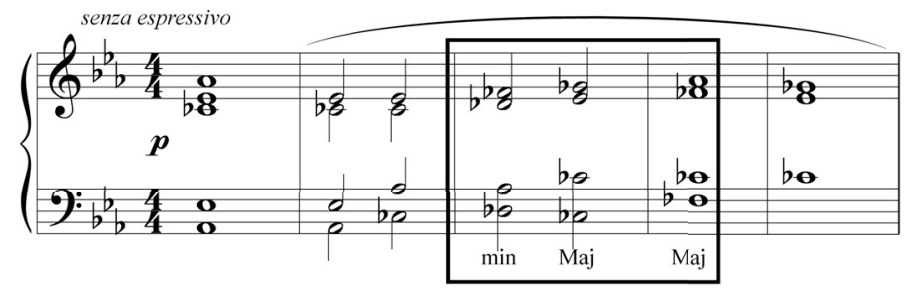

The second time of hearing the whole chant, it is repeated, again senza espressione, beginning in 'e flat minor', moving to 'G flat Major' (bb. 64-68). Melodically, the notes heard on both occasions are the contiguous sub-dominant, dominant, and sub-mediant of the tonic of 'C flat Major'.

This highlights the unusual use of the three-chord progression by being within a phrase, and not at the beginning of one or at a cadence point, as in the other examples. It moves slowly, and appears to be like a chant as part of a religious service, or a procession of chanting monks, heard at a distance; they form a stark contrast to the loud, celebratory description of the Great Gate, which might probably be a symbol for a some sort of State or City ceremonial occasion. In effect, this can be considered as a contrast of the secular on the one hand and the religious on the other.

However, it is the lead into the final hearing of the main theme, just 14 bars from the end of the piece, which merits our attention. Musical example (xvii) shows how it looks, where the bar marked 'Grave' is actually the first chord of the main melody and heralds its final performance. It is preceded by a cadence, comprising chords vi, $\mathrm{V}$ [and so to chord I] in E flat Major:

13 Strangely enough, there is a similarity between one of the variant hearings of the main tune, and the music at rehearsal figure $\mathrm{V}$ in the Bruckner example. While the melody moves up slowly through the three contiguous notes, both composers use a descending scalic figure in fast moving semiquavers. However, the harmonisation of the main tune at this point in both examples, uses a different harmonisation from the three-chord sequence discussed in this article. 
Musical example (xvii):

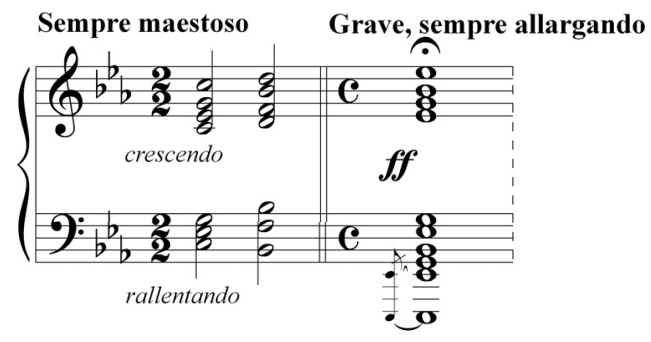

Of note, this music consists of very slow moving chords, here shown in the original piano version, with the composer's markings of rallentando, crescendo and sempre maestoso, ff, grave, and sempre allargando. In short, this means a slowing down of pace, with very loud sounds increasing in volume, played very slowly and broadly, while becoming increasingly slower. Such music can't help but stir the soul of the listener.

\section{Piotr I. Tschaikovski}

Like the opening of Also Sprach Zarathustra, the 1812 Overture, as it is popularly called, is also one of the most well-liked pieces in the orchestral repertoire. Tschaikovski (18411893), begins his overture with a harmonised statement of the Orthodox hymn, 'O Lord, Save Thy People', ${ }^{14}$ a Tropanion of the Holy Cross. Its Orthodox use is to ask God's help, and in this case, His help to win the Battle for Moscow against the invading French. The whole piece begins with the now-familiar melodic outline of the tonic, supertonic, and mediant notes.

The composer sets the Overture in 'E flat Major'. It is the third phrase of the whole piece, which uses the three-chords in bars 8-9; these are repeated almost immediately with a different orchestration, at bars 16 and 17. The whole chant is performed again at the end, largo, with crotchet $=60$, by full orchestra plus optional brass band, fff. This fuller version is also part of musical example $(\mathrm{xv})$.

On the final hearing at the end of the work, each phrase of the chant is punctuated by a pause, filled in with semi-quaver passages from the strings over tolling bells, representing the joy and happiness expressed by Moscow's population. We therefore hear the threechord sequence extremely loudly, slowly and each chord very exposed; all this represents a highly spiritual, religious context of thanking and praising God for His help.

14 Spasi, Gospodi, lyudi Tvoya in Russian. 
Musical example (xv):

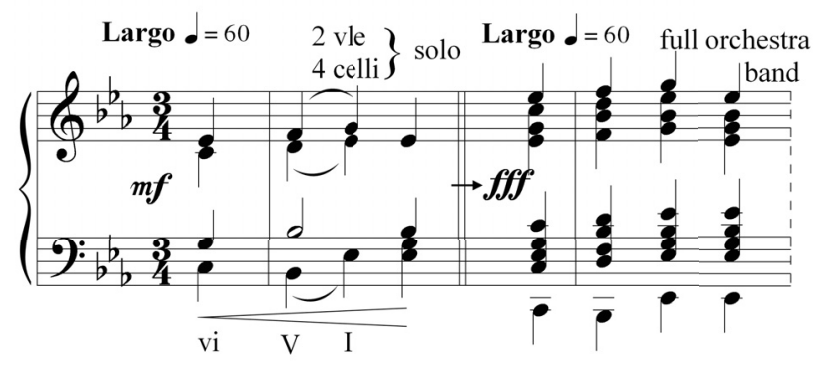

What is interesting to note is that Tschaikovski has actually changed what appears to be the 'original' harmony of this chant; the original from the $18^{\text {th }}$ century can be heard in two performances in recordings by the Stavyanka Male Chorus, and the St Daniel's Monastery Choir, conducted by Georgy Safonov and is seen in musical example (xvi); the harmonisation corresponds to that shown above in musical example (iii), version 2 .

Musical example (xvi):

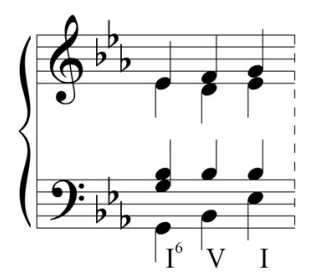

The question to ask is why did Tschaikovski change the harmony. Apart from any obvious reason, such as Tschaikovski using the tune with its harmony from memory, rather than checking it from the written original, it is perhaps for this reason: maybe the harmony he chose suited the situation better that the music is representing - that is, a prayerful and urgent petition to God, to save His people (the Muscovites) from attack, best represented by the three-chord sequence of this article.

\section{Nicolai Rimsky-Korsakov}

In The Russian Easter Festival Overture, Rimsky-Korsakov uses three Orthodox chants: (i) Let God Arise; (ii) An Angel Wailed; and (iii) Christ has Risen! The first two chants form the body of the Overture, during which they undergo variations, scarcely heard twice in the same format.

The third chant, Christ has Risen, is only used once and that is in the Coda of the whole work, thus forming its mighty climax. It is preformed by the brass instruments, $f f$, 
and slowly. According to Rimsky-Korsakov's explanation, it represents everyone in the Resurrection service of Easter Day praising God, with a great, resounding Alleluia.

The work opens with a monadic version of 'Let God Arise!', and then immediately in a sparse harmonic version, as in musical example (xvii).

Musical example (xvii):

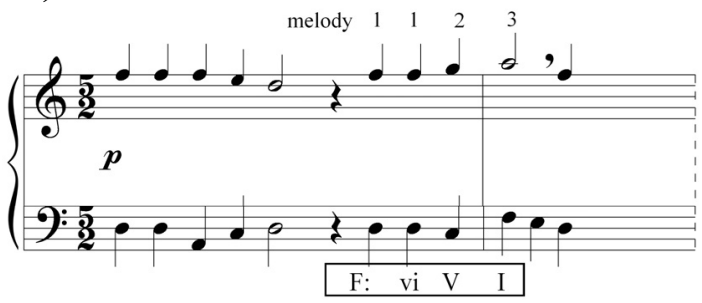

The melody contains the three contiguous notes, and the composer uses it as a brief modulation from 'd' minor to F Major. The chords are not completed in three-part harmony, but with the bass part, they hint at the three-chord sequence, as can be clearly seen in the musical example, and identified due to its very sparseness. It is significant to note that the three-chord sequence occurs after a brief moment of silence, and at the beginning of a phrase. It therefore clearly stands out in a highly religious context.

The second chant, An Angel Wailed, heard as the traditional second subject of the overture, also undergoes variation treatment. Musical example (xviii) shows again that Rimsky-Korsakov uses a sparse texture, whose bass line provides the outline of the three chords. The striking feature is that he immediately uses the same chords in reverse, which has already been noted as the popular version of these three chords, as in the Pachelbel version, musical example (iv) above.

Musical example (xviii):

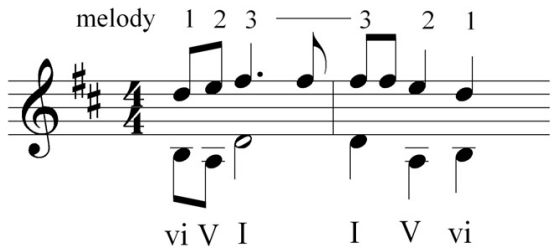

It is heard in both fast and slow versions as means of varying its use, and the latter is notably heard as a trombone solo, like a monk chanting, on several occasions. The second of these occasions, each phrase of the chant is separated by the full orchestra playing homophonic material in complete musical opposition to the chant. The whole work finishes with this particular chant.

Chant three, which occurs just the once, is heard in slow moving brass, $f f$, against the whole orchestra, including bells, at figure $\mathrm{Y}$ of the musical score. The words of the 
original chant are from the Easter Day service - Christ has Risen [or is Risen], Alleluia. Melodically it climbs upwards by step through nearly an octave, echoing the actual idea of Christ rising up. (This melodic statement is similar to the Beethoven and Weber examples, which similarly ascend by step through seven contiguous pitches). The three-chord sequence opens the hearing of the chant to 'F Major', as shown in musical example (xix), and then again later in the phrase in 'C Major':

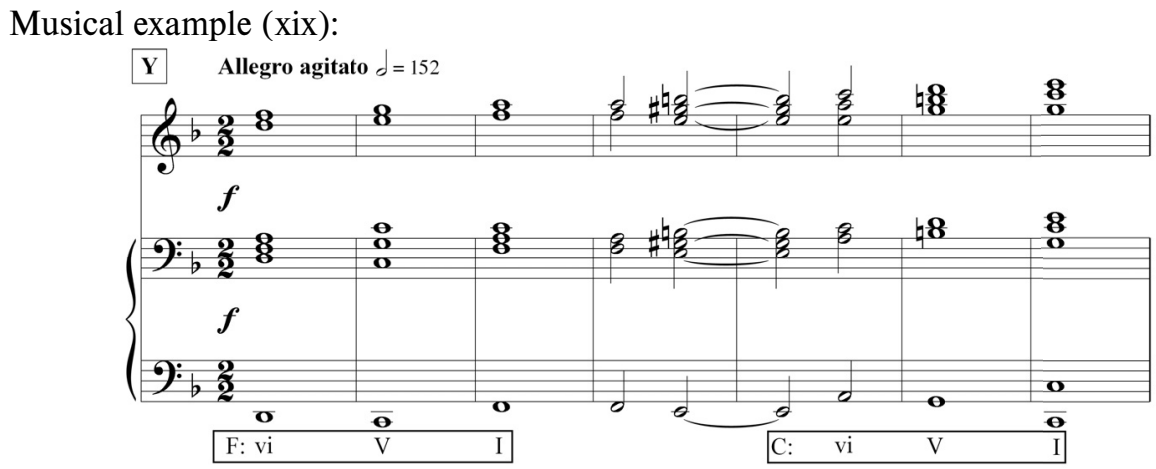

Harmonically, it appears that the chant begins in 'd minor'; however, it immediately moves to 'F major' three bars after figure Y. Then, in bars 5, 6 and 7, it moves finally to ' $\mathrm{C}$ Major', and thus becomes a further example of a ' $\mathrm{C}$ Major' version of the sequence, as heard in two of the Strauss examples above, for example. The shape of the melody moves by step across the seven bars. This Beethoven and Weber examples similarly move up by step in their melodic outlines.

\section{Gustav Mahler}

Mahler uses the three-chord sequence on one emotionally highly-charged occasion. The sequence actually forms the first two bars of his song, Urlicht, originally dating from 1892 , and the only one that is a statement in its own right, without a modulation into or out of the sequence. He was soon to use the entire song again in 1895 as the fourth movement of five in his Symphony no.2, 'The Resurrection'. The song is published in various keys, including 'E flat Major' as shown in musical example (xx) below. In the Symphony, it is in the warmly rich key of 'D flat Major', accompanied by strings, very softly, in standard four-part harmony. 
Musical example (xx):

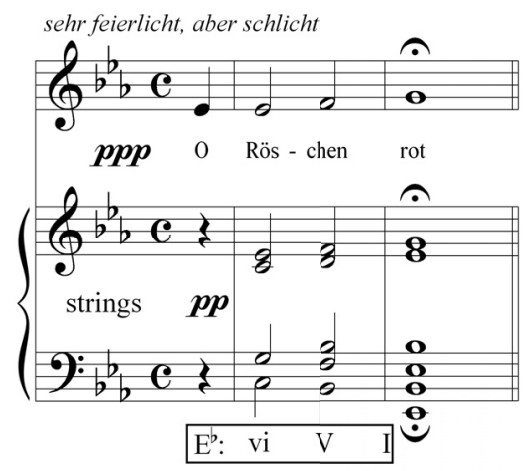

Melodically, it is the first three notes, tonic, supertonic, and mediant, employed by Mahler. The text comprises the four syllables of the words: $O$ Roschen rot! In English, this translates as 'O, Little Red Rose' and it continues with a brief story of a soul's life-long journey towards the afterlife. The text was often used as a prayer or possibly set as a hymn, at a funeral. For this article the important point is that Roschen rot refers symbolically to both Jesus and the Virgin Mary. ${ }^{15}$ The composer's instructions are: ppp, sehr feierlich, aber schlicht - 'sparse, and with ceremony'.

There are several overlaps with other examples above - slow moving, ceremonially played, and used in a religious context, and the wider context of the Resurrection story (strongly linking it spiritually with the version by Rimsky-Korsakov).

There is a notable similarity between the Mahler example, and the cadence of the last song of the four, by Richard Strauss, discussed above. The main difference is that in the Mahler song, the three chords are the very opening musical statement, and then come to a lengthy full stop, followed by a brief silence; with Strauss, they form the final cadence and almost the final cadence to his musical life, musically dying away to nothing at the end of the song. For this author, the effect in both the Mahler and Strauss songs, is indescribably beautiful, uplifting spiritually, and the context of both pieces take us to a place beyond life itself.

\section{Ralph Vaughan Williams}

The premiere of the Symphony no. 1, 'The Sea Symphony', by Vaughan Williams (18721958), occurred in 1910. It is a completely choral symphony, with each of the four movements using poetry from Leaves of Grass by the American poet, Walt Whitman

15 This symbolism is written about elsewhere, including: Greg Hurworth, 'Bernstein on Mahler: The Little Drummer Boy (1985),' in After Mahler's Death, eds. G. Gruber, M. Solvik, and J. Vičar (Olomouc: Palacký University, 2013), 102. 
(1819-1892). The texts chosen by Vaughan Williams concern the journey of the soul, and the enormous power possessed by each individual soul that goes beyond earth and out into the boundless universe on its journey. Therefore, the whole symphony is involved with the idea of journeying forth during one's earthly life to unknown, exploratory regions, unimaginable until experienced. Sailing the seas is the metaphor used by Whitman and so well understood by Vaughan Williams for that very journey of going beyond the horizon into the unknown, as each of us experience.

For this article, it is the final movement, with text from the section 'Passage to India', that takes our attention. The three-part chord sequence is heard with two sets of words: let's examine the first passage: ' $O$ Thou transcendent. Nameless the fibre and the breath. Light of the light ..., which is seen as musical example (xxi):

Musical example (xxi):
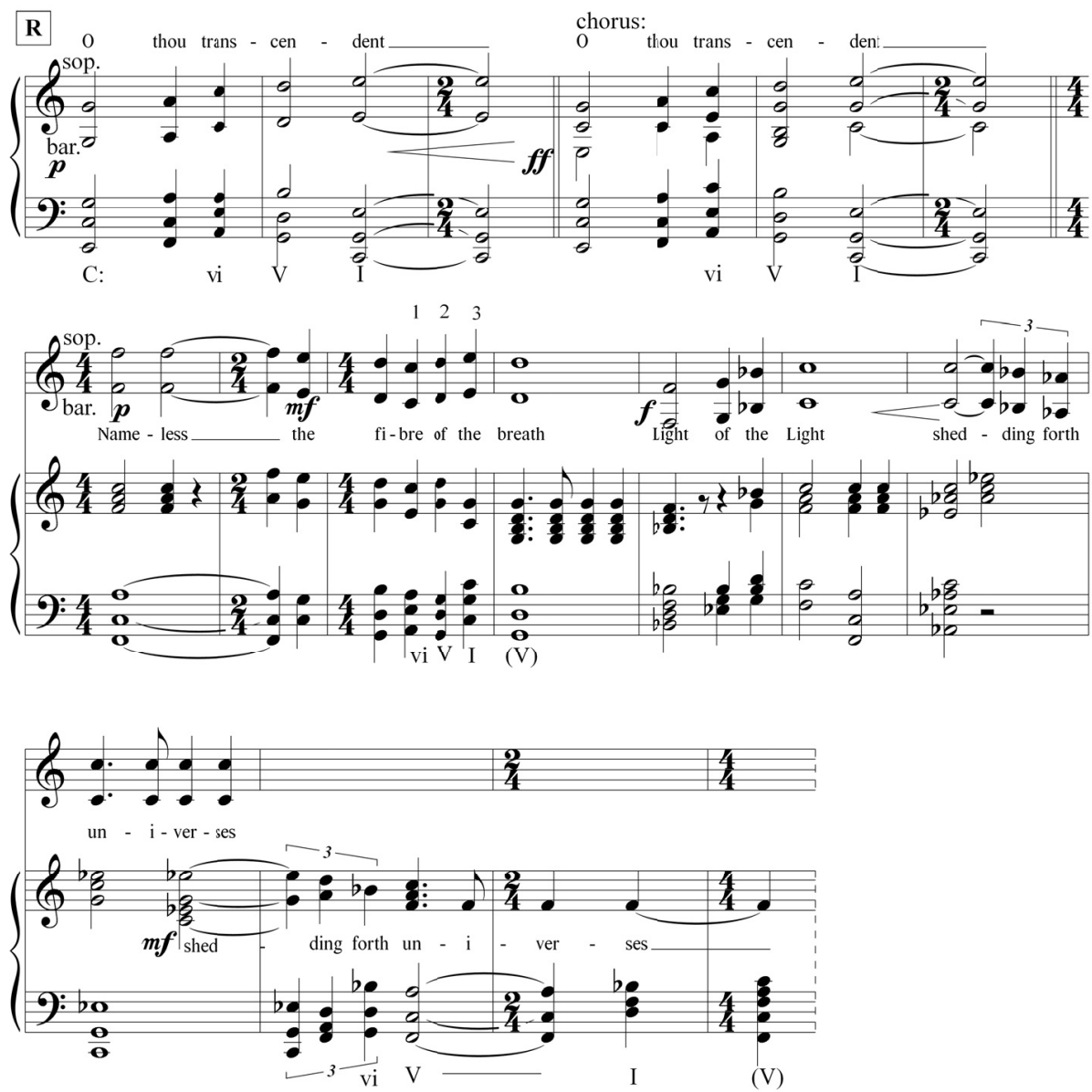
In musical example (xxi), we hear the words, 'O thou transcendent' twice. Firstly, exposed and sung by the two soloists (soprano and baritone) in octaves supported by the orchestra, providing the harmony. This is immediately repeated, much louder, by the full chorus. The two soloists then continue with the text, 'the fibre and the breath', which refer to the body, matter, in which is housed the soul. There is a brief modulatory section through 'B flat Major' and 'A flat Major', both of which include two of the three chords in the sequence.

This text refers to the soul being capable of transcendence - of moving beyond ordinary human experience, out into an other-worldly space - a clear reference to the universe, which is limitless and beyond our comprehension. It appears highly significant that a recent documentary about Vaughan Williams has been given the title, 'O Thou Transcendent'; ${ }^{16}$ this title has been used in order to show how the life and works of Vaughan Williams took music (and us, the listeners to his music) on a spiritual journey, which didn't end until his death at the age of 85 . Its choice as a title for the documentary of his entire life and output also highlights the fact that this Symphony, written in his mid-30s, is among the most original, and significant of his entire output. Musically, it contains much that is quintessential Vaughan Williams.

The second hearing of the chord sequence uses the text: 'Greater than stars and suns, Bounding $\mathrm{O}$ soul, thou journeyest forth!'. This forms musical example (xxi).

Musical example (xxi):

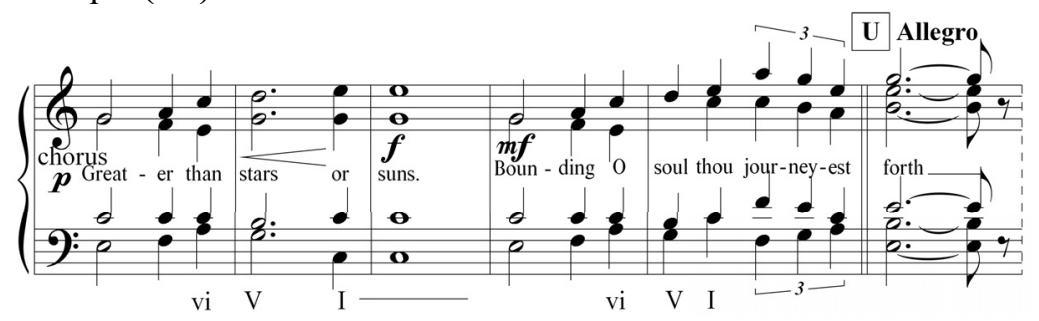

In this second example leading into rehearsal figure $\mathrm{U}$, there are two more hearings of the sequence, again both in 'C Major', as with its original hearing at figure R. It is by the Chorus alone, with a crescendo from piano to forte, from mezzo forte to fortissimo and a change of pace at figure $\mathrm{U}$. The tempo for all this section is slow, so that the chord sequence is once again easily registered, highlighted and so underlined, as in virtually all the occasions discussed above. The text of this second hearing of the three chords is: '(greater) than stars or suns [...]' and 'O soul, thou (journeyest forth) [...]'

Clearly, all five full hearings of the three-chord sequence (plus one partial version) in just three and a half minutes of music, and nowhere else in the whole work of seventy minutes, are at the heart of the entire piece; the text consistently refers to the soul, 'thou

16 Oh Thou Transcendent: The Life of Ralph Vaughan Williams. Tony Palmer, UK. Released January $1^{\text {st }}, 2008,2$ hours 29 minutes. It contains 32 scenes, and is the first exhaustive documentary of the composer's life and work. 
actual me', reaching out to the 'regions infinite' while being 'bathed in God'. In all hearings, the three-chord sequence appears at the end of a short phrase, as the cadence in 'C Major', with the note values lengthening in value, effecting a slowing down.

In other words, on each occasion, it is heard as a point of arrival, a place for a small pause, allowing us time to digest the material, before the music/thoughts/meanings move on. The fact that the first hearing - 'O Thou transcendent' is heard twice, one after the other, increasing in texture, volume and intensity, draws attention to these words set to the three-chord sequence.

Vaughan Williams used the sequence at least once more, in 1923, at the very beginning and elsewhere, in his one-movement work, Sea Songs. ${ }^{17}$ This work consists of arrangements of three folk tunes in $\mathrm{G}$ major, and the composer begins the music with an 'e minor' chord, repeated three times, then followed by D major, and finally with a G major chord - in other words, chords vi, V and I in G major. The fact that this is part of his Sea Songs for Brass Band, makes a direct link, consciously or sub-consciously by him, with his previously written 'Sea Symphony'.

\section{Discussion: a common ground of meaning}

It is evident from this brief excursion through each of these examples, that there are some strong overlaps in the ways that composers have imbued meaning in their music by use of these three chords. For example, the three-chord sequence is heard slowly - and sometimes, very slowly indeed; plus, the note values are long and often lengthen during the sequence, thus drawing individual attention to the nature and character of each of the chords within the sequence. In addition, the volume, and so intensity of the setting, increases throughout the three chords, and, this forms part of the overall contextual meaning. Here follows a synthesis of the contextual ideas present in all thirteen musical examples, to form a simply hypothesis.

Marin Alsop, the American conductor has introduced the Strauss setting from Also Sprach Zarathustra as 'one of the most recognisable musical excerpts in history [...] what makes a piece of music resonate with so many people?' she asks. The answer she

\footnotetext{
Sea Songs is a single movement March based on three sea melodies, namely The Princess Royal, Admiral Benbow and Portsmouth. The melody, 'Portsmouth', was first published in 1701, as part of John Playford's The Dancing Master. It is occasionally referred to as the Portsmouth Hornpipe - a sailor's dance. This author first knew Vaughan-Williams' arrangement because it was used as the signature tune for the quintessentially English television programme, Billy Bunter of Grayfriar's School, broadcast by the BBC from 1952 to 1961 . This choice of music for something so utterly English accentuates the very English nature of the music, too. The sea as a dominating theme in English music, folk-dance, drama and painting, displays its importance within British/English culture. Britain is, after all, surrounded by the sea, and the population is a mixture of waves of migrants from Continental Europe who have moved there over the past millennia. Britain's history and culture are therefore dominated by the effects of being an island-nation, and by the sea itself.
} 
provides is that 'the trumpets enter in unison, playing a fanfare-like figure based on perfect intervals. Perfect intervals give a sense of possibility and vastness. I immediately think of Copland's Fanfare For The Common Man [...] the effects are identical: strength, breadth, optimism, possibility [...] Strauss repeats the opening fanfare three times, each time gaining in intensity, until it finally breaks free and arrives at a majestic cadence in the key of C major - the universal key [...]'. What she terms as this 'majestic cadence', of course, is the very three-chord sequence, which is the subject of this article.

Alsop continues: 'We feel $\mathrm{C}$ major in a very primal way as human beings [...] when Kubrick chose this opening music for 2001: A Space Odyssey, his desire was to elicit that same emotional response from viewers: to contemplate the vastness and possibility of the universe and to bring forward the same questions that Nietzsche proposed in 1885 about God, about humankind and about our existence here in the natural world [...] Nietzsche wanted us, as human beings, to reconsider our value system and [...] start to hold ourselves accountable for our own actions $[\ldots]^{\prime 18}$

Another recent conductor of the Strauss work, Gustavo Dudamel talks of that famous opening, by indicating that 'Strauss' interpretation and conception of Nietzsche, that clear idea of the power possessed by human beings, the individual divinity within all of us - it's all implicit in his music ... ${ }^{19}$

If we now broaden these views to examine Vaughan Williams' use of the three-chord sequence, also in 'C Major', we can see that there are common religio-philosophical ideas behind these settings - a description of the soul, and its relation to the world, to the universe, to the idea of God, to the power of the soul to transform an individual, or groups of people, communities, and even the world. In other words, something common to our quintessential humanity, meaningful to us all, to what has gone in the past, is present right here now for us to consider (after all, 2001 of the film, has long passed), and for the future of humankind.

Here we have the essence of the examples in this article, and perhaps most clearly with the message in the Vaughan Williams' work; his symphony has the same questioning subject matter. Also, the Resurrection examples point us towards answers to the big life questions, of where God fits into our lives, and what happens to our souls after death; the big life searches all of us experience at some time or other as questioning, emotional beings, set on a small planet in a vast, incomprehensibly massive universe is a common theme of these musical examples. There is nothing more philosophical, and indeed, religious that can unite both humanity, its thinking and its music.

18 Decoding Strauss' Tone Poem, January 13, 2012, heard on Weekend Edition Saturday Marin Alsop. NPRMusic.org, from an interview with Scott Simon for NPR News.

19 Gustavo Dudamel quoted in Zarathustra: The Universe according to Strauss. Melissa Lesnie, January 24, 2014, 'Limelight Magazine', ABC, Australia; accessed from www.limelightmagazine.com.au, May 7, 2016. 
God is therefore an important part of this thinking, and the Russian examples all exist due to a human belief in a loving and helping God, who has built the Universe, and saw that it was good. The Rimsky-Korsakov example indeed comes from the central idea of Christianity - that God sent His son, who died and rose again from the dead. The power, mentioned by Marin Alsop as being present in the Strauss, is also there in each and every one of the musical examples. The Tschaikovski, and to a lesser extent, the examples in Mussourgski, represent other tenets of Christianity - of God helping His people in a positive way - we are His and He is ours, and He will help save us from catastrophe and complete annihilation.

The fact that the Soul as representative of our very nature as humans, is also found in the Monteverdi with the setting of the word, 'magnificat' referring to Mary's soul magnifying the Lord, while Mary's spirit rejoiced in God, her Saviour. Again, this is a central part of the life of Jesus, and Mary as the mother of God the Son, as critical to Christianity. The Mahler example also refers straight back to the relation of Jesus and Mary, as shown by the symbolic use of the red rose - the bleeding heart of Jesus, and Mary, the mother of God, the Son. He used it within the context of resurrection of the soul. We will all rise up and live again.

The fact that a slow movement in a Bruckner Symphony, following on from those of Beethoven, is spiritual, spirit-filled experience for both the performer and listener, is magnified in the example shown in this article. Bruckner even appended some of his works with dedication 'dem lieben Gott' - to his beloved God, which show the religious nature behind the inspiration for his music. ${ }^{20}$ Indeed, the sequence of three chords in the Bruckner, exemplifies most of the musical characteristics found in the other examples slow moving, long notes, a crescendo, warm-sounding stringed instruments predominating in simple four part harmony, in a context of a spiritual experience; they form a summary of the sparing and sparse use of these three chords in sequence by composers across 350 years.

The final symbolic meaning behind the three-chords, is that they are often used within a modulation, where a modulation shifts us in meaning from one level to another, musically. The fact that this musical material is from a minor scale tonality to a Major, is quite a shift of place and time, to another level of thought, meaning and ideas.

The very rarity of this harmonic progression of three chords, already makes it worthy of scrutiny. In addition, the context for each of the uses of this chord sequence is remarkably similar, or overlapping in their symbolic meanings. These facts alone lead this author to propose that these three contiguous chords represent an aspect of the religiophilosophical nature of humanity; they confirm the basic spirituality of us all that is not possible to put into words, but we can all hear and feel passionately in musical sound. In other words, these three chords can be considered as our souls portrayed as reflection of

20 An example of this is his unfinished Symphony no. 9 in d minor, with its spiritually-charged, Beethovenian third movement: adagio, langsam, feierlich - 'ceremonially slow', is very much related to the other works mentioned in this article. 
God, in music. It is almost like we can say that these three chords in sequence are a 'gift' from God - they are His symbol, built into music to remind us of Him and His presence in our spiritual life both now and whenever this music is performed in the future.

\title{
Defining Moments of the Spirit and Soul in Music
}

\begin{abstract}
This article represents an attempt to describe the use of a sequence of three-chord, comprising the sub-mediant, followed by the dominant and thirdly, the tonic by composers from 1610 (Monteverdi) to 1948 (Richard Strauss). During that time, this three-chord sequence has been used sparingly - by just nine composers - but is used in two of the most well-known and loved orchestral works. The author poses the questions: why has it been used so infrequently? What is the contextual meaning of this chord sequence by each composer? Is there anything significantly similar between the meaning of the chord sequence across all the works of these nine composers? Surprisingly, there was no use of this chord sequence between Monteverdi and Beethoven. After investigation, the author shows that the reverse of the sequence, tonic, dominant, sub-mediant chords, was a standard sequence in works from the Baroque through to the present day, often as an ostinato pattern. From Pachelbel's Canon in D to songs by the Beatles, Bob Marley, and many other famous, contemporary singer-song writers. On the other hand, the author shows that the use of the three-chords, is either as cadence or at the beginning of a phrase; it can also be used as a means of modulating, from a minor to a Major key. From Monteverdi on through the list, the contextual meaning of the sequence, sometimes with a text, and sometimes without, has a religio-philosophical spiritual meaning and use. Most of the composers set the sequence to a Christian text (Magnificat, Easter hymns, Resurrection) while others use folk texts or celebrated poetry, to describe philosophically the journey of the soul from birth to death and beyond.
\end{abstract}

\section{Určující momenty Ducha a Duše v hudbě}

\begin{abstract}
Abstrakt
Studie se pokouší ukázat využití sekvence tří akordů, respektive harmonických funkcí (konkrétně spodní medianty, za níž následuje dominanta a tónika) u skladatelů v období od roku 1610 (Monteverdi) do roku 1948 (Richard Strauss). V průběhu tohoto období byl zmíněný harmonický postup použíán pouze zřídka (pouze u devíti skladatelů), objevuje se ale ve dvou nejznámějších a nejoblíbenějších orchestrálních skladbách. Autor si klade následující otázky: proč je využíání dané sekvence tak ojedinělé? Jaký je kontextuální význam sekvence v dílech jednotlivých skladatelů? Existuje zde společný
\end{abstract}


významový jmenovatel? Je překvapivé, že se uvedená sekvence tř́i akordů od Monteverdiho po Beethovena téměř nevyskytuje. Na základě výzkumu autor ukazuje, že obrácený sled harmonických funkcí či akordů dané sekvence (tedy tónika, dominanta, spodní medianta), je v hudbě od baroka až po současnost naopak velmi frekventovaný, často jako ostinátní harmonický základ skladby. Př́kladem může být Pachelbelův Kánon v D-dur, stejně tak skladby the Beatles, Boba Marleyho a mnoha dalších slavných současných skladatelů a písničkářù. Autor ukazuje, že pojednávaný harmonický sled může fungovat jako kadence či jako úvodní fráze; může být rovněž využitý jako prostředek k modulaci z mollové do durové tóniny. U Monteverdiho a dalších pojednávaných skladatelů má sekvence, jež je v některých případech doprovázena literárním textem, nábožensko-filozofický význam a funkci. Většina skladatelů ji doprovází křestanskými texty (Magnificat, Velikonoční hymny, Vzkř́išení), někteří využívají lidové texty či oslavnou poezii s cílem filozoficky vyjádřit putování duše od zrození k smrti a po ní.

\section{Keywords}

Three-chord sequence; use and meaning of the sequence; religio-philosophical meaning defined in music; the human spirit and soul in music.

\section{Klíčová slova}

Akordická sekvence tří harmonických funkcí; funkce a význam sekvence; nábožensko-filozofický význam vyjádřený prostř̌ednictvím hudby; lidský duch a duše v hudbě. 